\title{
Radon Monitoring in Groundwater and Soil Gas of Sakhalin Island
}

\author{
Chelnokov Georgy'1, Zharkov Rafael'2, Bragin Ivan' \\ ${ }^{1}$ Laboratory of Hydrogeochemistry, Far East Geological Institute Far East Branch Russian Academy of Sciences, \\ Vladivostok, Russia \\ ${ }^{2}$ Department of Volcanology, Institute of Marine Geology and Geophysics Far East Branch Russian Academy of \\ Sciences, Yuzno-Sakhalinsk, Russia \\ Email: geowater@mail.ru
}

Received 27 March 2015; accepted 10 July 2015; published 17 July 2015

\begin{abstract}
A groundwater radon monitoring in the southern and western part of Sakhalin Island was carried out in 2014 in order to study the correlation between radon anomalies and the seismic activity of the region. The objects of investigations were located within large tectonic dislocations of the island - the southern part of the Central Sakhalin fault and the central part of the West Sakhalin fault. The soil gas monitoring was carried out using a Sirad probe (Quarta-Rad, Russia) and the continuous radon monitoring in the groundwater was carried out using a Radon Seismic Station (CPC-05, NTM-Zashita, Russia). The effect of geochemical parameters, namely, temperature, pressure and conductivity on the radon emission has been studied. The present work contains an analytical protocol which is based on the analysis of radon emitted from the fault planes, a geochemical precursor when predicting the tectonic activity.
\end{abstract}

\section{Keywords}

Radon, Sakhalin Island, Tectonic Activity, Mud Volcano, Earthquake Precursor

\section{Introduction}

The objects of investigations are located within large tectonic dislocations of the island. The Sinegorski spa of a high $\mathrm{pCO}_{2}$ mineral water and the Yuzhno-Sakhalinski mud volcano located within the southern part of the Central-Sakhalin fault have been studied. Inside the central part of the West-Sakhalin fault the Volchanski spa of a high $\mathrm{pCO}_{2}$ mineral water and the Lesogorski thermal spring have been studied (Figure 1). A groundwater radon monitoring was carried out in the summer of 2014 in order to study the correlation between radon anomalies and the seismic activity of the region.

It is argued that radon is a useful geochemical precursor. Anomalous behavior of radon in soil and groundwater is considered to be as a reliable impending earthquake precursor [1]-[12].

Investigations throughout the world over the past 20 years provide the evidence indicating that significant variations of the radon concentration may occur in association with major geophysical events such as earth- 


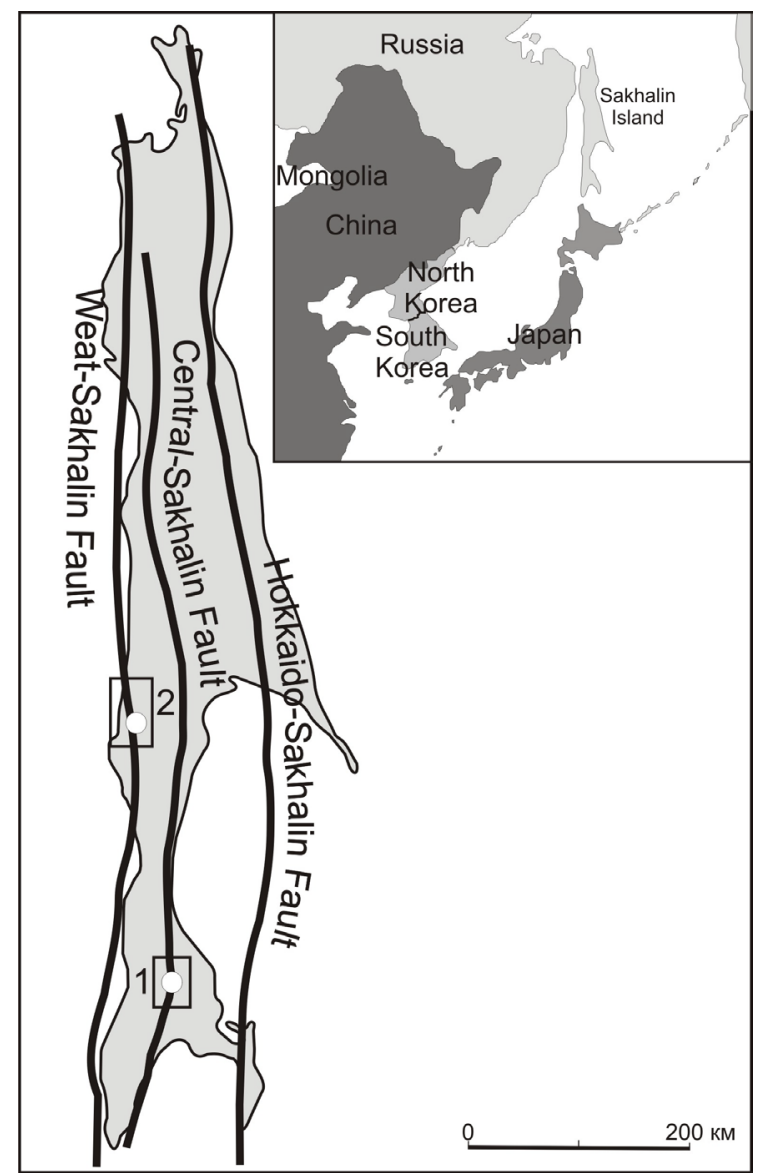

Figure 1. Geographic setting, main tectonic dislocations and location of study areas. 1-South-Sakhalin mud volcano and Sinegorski Spa; 2-Volchanski Spa and Lesogorski thermal spring.

quakes and volcanic eruptions [1] [5] [11]-[15]. Due to the mentioned above correlation, radon is considered to be one of few potential earthquake precursors.

The program of radon monitoring at the Sinegorski spa and the Volchanski spa was initiated in June 2014 as a part of the present investigation. The continuous groundwater gas monitoring has been carried out using a Seismic Radon Station (SRS-05). Such physical parameters as temperature, pressure (water level) were being measured continuously by Solinst baralogger (Canada) and conductivity by a logger LTC F100/M30 (Canada). Physical parameters like temperature, pressure (water level) were measured continuously by Solinst loggers LT M30/F10 (Canada) and conductivity by logger LTC F100/M30 (Solinst, Canada).

\section{Geology and Hydrogeology}

The Sinegorski spa of a high $\mathrm{pCO}_{2}$ mineral water and the associated Yuzhnj-Sakhalinski mud volcano are located on the west border of the Aniva depression. The geological structure of a cretaceous complex within the Sinegorski spa has been studied well in a number of works [16]-[18]. A parametric well discloses the sandstone aquifer of Maruyamsky formation of Pliocene-middle Miocene age. The oldest formation in the area is Mesozoic rocks which consist of micaceous and quartz shales, marble and quartzites, siltstones, mudstones, sandstones and tuffs. All sediments of the cretaceous system had been accumulated in marine conditions.

The southern part of the Central-Sakhalin fault is in the Susunayski artesian basin in terms of hydrogeology. Hydrogeological conditions of the territory are very complex and caused by a zone and block structure, fracture permeability. The zone of an active water exchange makes not more than $100 \mathrm{~m}$ from the surface and is caused by weathering. Water of the top aquifers is free-flow, fresh, hydrocarbonate. Mineral water of the deepest aqui- 
fer has mineralization of $10-30 \mathrm{~g} / \mathrm{l}$ and $\mathrm{Cl}-\mathrm{Na}$ or $\mathrm{HCO}_{3}-\mathrm{Cl}-\mathrm{Na}$ composition. The associated gases are presented by $\mathrm{CO}_{2}$ and $\mathrm{CH}_{4}$.

The Volcanski Spa and the Lesogorski thermal springs are located in the western part of Sakhalin, in Uglegorsk region. The high $\mathrm{pCO}_{2}$ mineral water is associated with zone fractured sedimentary rocks of Arakayski formation of upper Paleogene, and has the area of about $0.02 \mathrm{~km}^{2}$. It is covered by a clay cap on the surface. Formation of the spa is caused by the deep fluids enriched with carbon dioxide, bromine and iodine. Mineralization of water is $6-8 \mathrm{~g} / \mathrm{L}$.

\section{Hydrogeochemistry and Isotopes}

The parametric well No. 8-Kl-1 contains a Cl-Ca-Na mineral water with free $\mathrm{N}-\mathrm{CO}_{2}-\mathrm{CH}_{4}$ gas (Table 1). The depth of well is $500 \mathrm{~m}$. Static water level is $+0.5 \mathrm{~m}$. Values of conductivity change from 12,969 $\mu \mathrm{S} / \mathrm{cm}$ on the surface to $13,328 \mu \mathrm{S} / \mathrm{cm}$ at depth. Mineralization of the water vary from 10.5 to $11.7 \mathrm{~g} / \mathrm{L}$. The well testing by temperature and conductivity loggers shows a lack of infiltration of a fresh underground water from annular space and mixing. Taking into consideration the geochemistry and isotopic composition of water it can be concluded that the water matches a metamorphic water of a marine genesis which is confirmed by a high content of $\mathrm{I}, \mathrm{Br}$ and $\mathrm{B}$, and low concentration of $\mathrm{HCO}_{3}$.

Water of the Yuzhno-Sakhalinski mud volcano have a Cl- $\mathrm{HCO}_{3}-\mathrm{Na}$ composition and TDS of 15.8 - $26.2 \mathrm{~g} / \mathrm{L}$. The associated gas composition is presented in Table 1. It is evident from the isotopic composition of gases that the Sinegorski spa and the mud volcano have a similar thermogenic source of $\mathrm{CH}_{4}$ and different genesis of $\mathrm{CO}_{2}$.

A mineral water of the Volchanski spa from the parametric well No 92 has a $\mathrm{HCO}_{3}$-Cl-Na composition, TDS 6 - $8 \mathrm{~g} / \mathrm{L}$, temperature $10^{\circ} \mathrm{C}$ and low content of Ca $(129 \mathrm{mg} / \mathrm{L}), \mathrm{Mg}(50 \mathrm{mg} / \mathrm{L})$ and $\mathrm{K}(15 \mathrm{mg} / \mathrm{L})$. The depth of well is $100 \mathrm{~m}$. Static water level is minus $1.5 \mathrm{~m} . \mathrm{CO}_{2}$ is a main component of bubbling gases. At the moment we don't have information about genesis of the Volchanski spa gases, but the He content of the gas is high-94 ppm, and indicates the connection with depth faults. Whereas a main gas of the Lesogorski thermal spring is $\mathrm{CH}_{4}$ and isotopic data show a bacterial genesis of methane as a result of oxidation processes. Thermal water have a $\mathrm{HCO}_{3}-\mathrm{Na}$ composition, TDS $0.15 \mathrm{~g} / \mathrm{L}$ and temperature $34^{\circ} \mathrm{C}$.

\section{Radon Monitoring}

Radon is considered to be an important tectonic activity precursor due to its limited informational content caused by a relatively short half-life period of 3.82 days. Since temperature and conductivity of water can control solubility of radon in the water these parameters are considered to be important.

A field laboratory equipped with independent loggers was constructed to observe correlation between these parameters. The well equipment construction is set out in Figure 2. Researches of radon-222 have been conducted both in the soil and in the well. Since according to geological data an active part of faults in a near-surface zone has the sizes not more than $800 \times 300 \mathrm{~m}$ for each investigation object, the area of Rn investigations is limited. A subsoil radon activity measurement has been taken using a grid of $100 \times 100 \mathrm{~m}$.

Table 1. Chemical and isotopic composition of the studied gases.

\begin{tabular}{|c|c|c|c|c|}
\hline Components & $\begin{array}{l}\text { The Sinegorski Spa, } \\
\text { well No 8-Kl-1 }\end{array}$ & $\begin{array}{l}\text { The Yuzno-Sakhalinski } \\
\text { mud volcano }\end{array}$ & $\begin{array}{l}\text { The Lesogorski } \\
\text { thermal spring }\end{array}$ & $\begin{array}{l}\text { The Volchanski spa, well } \\
\text { No } 92\end{array}$ \\
\hline \multicolumn{5}{|c|}{ vol.\% } \\
\hline $\mathrm{N}_{2}$ & 10.9 & 2.32 & 9.4 & 6.9 \\
\hline $\mathrm{O}_{2}$ & 0.89 & 0.28 & 1.9 & 0.5 \\
\hline $\mathrm{CO}_{2}$ & 0.01 & 81.12 & 0.4 & 60.6 \\
\hline $\mathrm{CH}_{4}$ & 87.17 & 16.1 & 81.5 & 31.9 \\
\hline \multicolumn{5}{|c|}{ \%о VPDB } \\
\hline$\delta^{13} \mathrm{C}_{(\mathrm{CH} 4)}$ & -27.5 & -28.1 & -45.9 & - \\
\hline$\delta{ }^{13} \mathrm{C}_{(\mathrm{CO} 2)}$ & -30.6 & -3.3 & -39.1 & - \\
\hline$\delta^{2} \mathrm{H}(\mathrm{CH} 4)$ & -84.2 & -72.3 & - & - \\
\hline
\end{tabular}




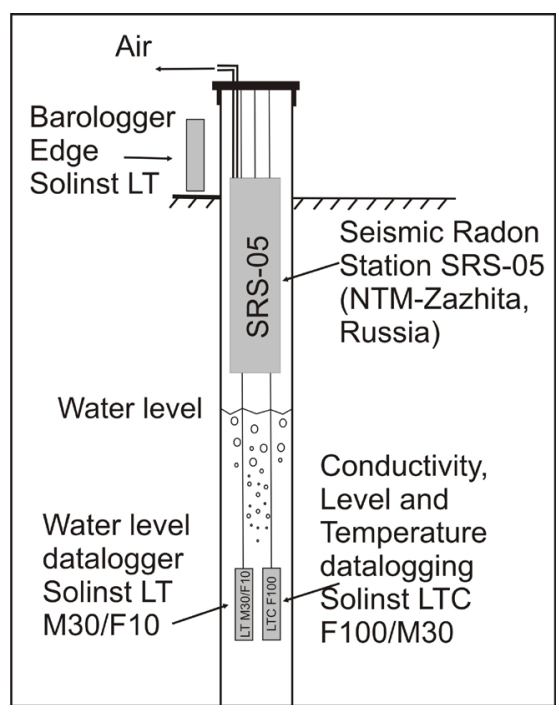

Figure 2. The scheme of the equipment of a parametric well.

\section{Results and Discussion}

The increase in radon concentration in soil gas or groundwater before an earthquake may be a result of the strain buildup in the area. During this process, very small fractures are formed in the rocks, which provides more radon contribution to the soil gas or water near the Earth's surface. A decreasing radon anomaly may occur as a result of the squeezing effect of compres-sional stress in the rock, which changes the porosity of soil at a microscale [5].

The investigations show that concentration of soil radon at the Sinegorski Spa is very low and varies from 42 to $64 \mathrm{~Bq} / \mathrm{m}^{3}$. Generally radon shows a positive correlation with temperature i.e., the value of radon concentration decreases with decrease in temperature and increases as temperature increases. The variation of radon concentration in soil gas along with the soil temperature was not detected. The increase in radon concentration and temperature may be a result of the increase in the diffusion rate and temperature [19] [20]. It is illustrated at the Lesogorski thermal field, where radon concentration in soil gas reaches $100 \mathrm{~Bq} / \mathrm{m}^{3}$. The area of the Volchanski Spa is characterized by the lowest soil radon concentration of $32-51 \mathrm{~Bq} / \mathrm{m}^{3}$. It could be connected with geological conditions of the area, since it is covered by a clay layer. It is well know, that many factors that affect the formation and movement of radon in the ground-the uranium content, grain size, and permeability of the host rock and the nature and extent of fracturing in the host rock [21]—are functions of rock type. We assume, that important factor affecting the amount of radon in groundwater in the Sinegorski spa and Volchanski spa is the associated gas composition and activity. Methane and $\mathrm{CO}_{2}$ manifestations indicates tectonically weak zones. Also, tectonic stress sustained by the sedimentary rocks in the collision zones results in mud volcano activity [22].

While of monitoring parametric wells a connection between changes of radon concentration, conductivity and water level has been found out (Figure 3). Temperature of water within the aquifer was stable during the monitoring period. However, sometimes abnormal concentration is not connected with any parameters (Figure 3(b)). One of the reasons could be unstable volume of spontaneously bubbling gases. At the moment this important parameter cannot be controlled.

Consequently obtained data show an ambient level of radon concentrations for the Sinegorski Spa from 3950 to $4900 \mathrm{~Bq} / \mathrm{m}^{3}$; emanations from the well of the Volchanski Spa are greater, from 5833 to $7216 \mathrm{~Bq} / \mathrm{m}^{3}$ and the Lesogorski thermal spring has the lowest concentration of radon, from 16 to $133 \mathrm{~Bq} / \mathrm{m}^{3}$. The anomalies are followed by conductivity or water level, but not connected with any seismic events during monitoring period. The difference between the nature of radon concentrations in soil and water may occur due to the difference in the radon source and geological conditions of the hypergenetic zone. Also the Volchanski spa lies exactly on the West Sakhalin fault system whereas the Sinegorski spa radon source is slightly away from the Central-Sakhalin fault. The studies [23] reveal that sometimes the anomaly cannot be observed even when the seismic event has 

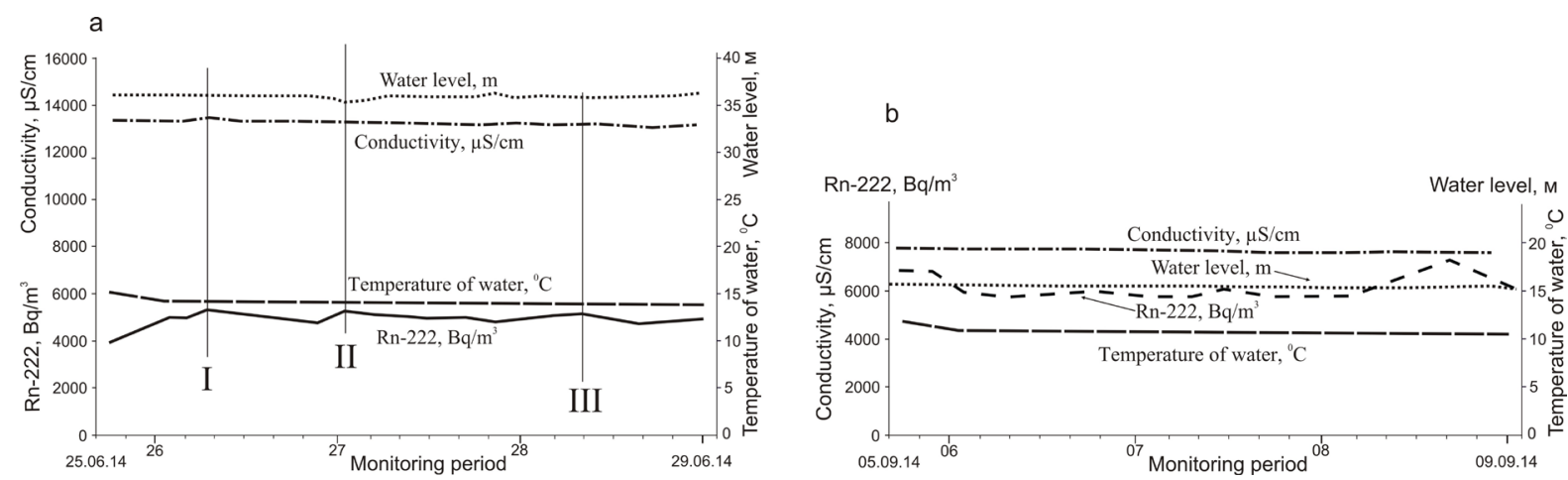

Figure 3. Daily variation of Rn concentration in groundwater at Sinegorski Spa (a) and Volchanski Spa (b).

occurred. This necessitates measurement of other carrier gases in addition to radon for successful prediction of earthquakes.

An enhanced radon concentration in the deep seated natural water and in the soil to a lesser extent is assigned to microcracks, fissure and fracture growth as a result of dilatancy prior to an earthquake. According to dilatancy mechanism for earthquake occurrence [24], when regional stress increases, dilation of rock masses is likely to cause an increase in the surface area of rocks due to cracking, or in the flow rate of pore fluids as they are forced out of the interstitial space. Both of these processes are considered to enhance radon transportation from its original enclosures into the groundwater.

\section{Conclusions}

Measurements of physical parameters and radon carried out for the first time allows draw the following conclusions:

1) The low level of soil radon concentration at all studied objects: the Sinegorski spa-64 Bq/m $\mathrm{m}^{3}$, the Leso-

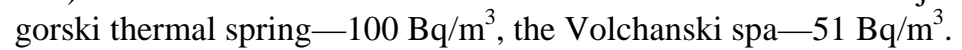

2) Emanations of Rn-222 from wells are characterized by the greatest values. Received data on radon concentrations for the Volchanski spa shows $5833-7216 \mathrm{~Bq} / \mathrm{m}^{3}$; for the Sinegorsky spa from 3950 to $4900 \mathrm{~Bq} / \mathrm{m}^{3}$; the Lesogorski spring of the thermal water has the lowest concentration of radon $16-133 \mathrm{~Bq} / \mathrm{m}^{3}$. The effect of geochemical parameters viz. temperature, conductivity on radon emission has been found out.

During the registration of geochemical parameters in wells, as well as while testing and setting the equipment, neither earthquakes more than 2.0 magnitude has been observed in the studied areas (data of Service of urgent reports of Geophysical service of Russian Academy of Sciences), nor eruptions of mud volcanoes have been noticed.

\section{Acknowledgements}

This study was supported by the Russian Foundation for Basic Research projects No 14-05-00243, 14-05-00171 and 13-05-00544. Part of geochemical investigations was made as a part of the Russian Scientific Foundation N 14-17-00415.

\section{References}

[1] Chyi, L.L., Quick, T.J., Yang, T.F. and Chen, C.H. (2005) Soil Gas Radon Spectra and Earthquakes. Terrestrial Atmospheric and Oceanic Sciences, 16, 763-774.

[2] Einarsson, P., Theodórsson, P., Hjartardóttir, Á.R. and Guðjónsson, G.I. (2008) Radon Changes Associated with the Earthquake Sequence in June 2000 in the South Iceland Seismic Zone. Pure and Applied Geophysics, 165, 63-74. http://dx.doi.org/10.1007/s00024-007-0292-6

[3] Fleischer, R.L. (1981) Dislocation Model for Radon Response to Distant Earthquakes. Geophysical Research Letters, 8, 477-480. http://dx.doi.org/10.1029/GL008i005p00477

[4] Igarashi, G., Saeki, S., Takahata, N., Sumikawa, K., Tasaka, S., Sasaki, Y., Takahashi, M. and Sano, Y. (1995) Groundwater Radon Anomaly before the Kobe Earthquake in Japan. Science, 269, 60-61.

http://dx.doi.org/10.1126/science.269.5220.60 
[5] Kumar, A., Singh, S., Mahajan, S., Bajwa, B.S., Kalia, R. and Dhar, S. (2009) Earthquake Precursory Studies in Kangra Valley of North West Himalayas, India, with Special Emphasis on Radon Emission. Applied Radiation and Isotopes, 67, 1904-1911. http://dx.doi.org/10.1016/j.apradiso.2009.05.016

[6] Liu, K.K., Yui, T.F., Yeh, Y.H., Tsai, Y.B. and Teng, T.L. (1984/85) Variations of Radon Content in Groundwaters and Possible Correlation with Seismic Activities in Northern Taiwan. Pure and Applied Geophysics, 122, $231-244$.

[7] Mogro-Campero, A., Fleischer, R.L. and Likes, R.S. (1980) Changes in Subsurface Radon Concentration Associated with Earthquake. Journal of Geophysical Research, 85, 3053-3057. http://dx.doi.org/10.1029/JB085iB06p03053

[8] Talwani, P., Moore, W.S. and Chiang, J. (1980) Radon Anomalies and Microearthquakes at Lake Jocassee, South Carolina. Journal of Geophysical Research, 85, 3079-3088. http://dx.doi.org/10.1029/JB085iB06p03079

[9] Ulomov, V.I. and Mavashev, B.Z. (1967) A Precursor of a Strong Tectonic Earthquake. Acad. Sci. USSR Earth Sci. Sect., 176, 9-11.

[10] Virk, H.S. and Singh, B. (1992) Correlation of Radon Anomalies with Earthquake in Kangra Valley. Nuclear Geophysics, 6, 293-300.

[11] Walia, V., Su, T.C., Fu, C.C. and Yang, T.F. (2005) Spatial Variations of Radon and Helium Concentrations in SoilGas across Shan-Chiao Fault, Northern Taiwan. Radiation Measurements, 40, 513-516. http://dx.doi.org/10.1016/j.radmeas.2005.04.011

[12] Walia, V., Virk, H.S. and Bajwa, B.S. (2006) Radon Precursory Signals for Some Earthquakes of Magnitude $>5$ Occurred in N-W Himalaya: An Overview. Pure and Applied Geophysics, 163, 711-721. http://dx.doi.org/10.1007/s00024-006-0044-z

[13] Al-Tamimi, M.H. and Abumurad, K.M. (2001) Radon Anomalies along Faults in North of Jordan. Radiation Measurements, 34, 397-400. http://dx.doi.org/10.1016/S1350-4487(01)00193-7

[14] Fu, C.C., Yang, T.F., Walia, V. and Chen, C.H. (2005) Reconnaissance of Soil Gas Composition over the Buried Fault and Fracture Zone in Southern Taiwan. Geochemical Journal, 39, 427-439. http://dx.doi.org/10.2343/geochemj.39.427

[15] Singh, S., Sharma, D.K., Dhar, S. and Randhawa, S.S. (2006) Geological Significance of Soil Gas Radon: A Case Study of Nurpur Area, District Kangra, Himachal Pradesh, India. Radiation Measurements, 41, 482-485. http://dx.doi.org/10.1016/j.radmeas.2005.10.009

[16] (1970) Geology of USSR, v. XXXIII. Sakhalin Island, Geological Description. Nedra, Moscow, 432.

[17] Key Section of Cretaceous Deposits of Sakhain Island (Naibinsky Section) (1987). Nauka, Leningrad, 196.

[18] Melnikov, O.A. (1988) Geological Formations of Hokkaido-Sakhalin Fault Zone. Vladivostok, 213.

[19] Sharma, A.K., Walia, V. and Virk, H.S. (2000) Effect of Meteorological Parameters on Radon Emanation at Palampur (H.P.). J. Geophys., 21, 45-48.

[20] Singh, M., Ramola, R.C., Singh, S. and Virk, H.S. (1988) The Influence of Meteorological Parameters on Soil Gas Radon. J. Assoc. Explor. Geophy., 9, 85-90.

[21] Otton, J.K. (1992) The Geology of Radon: U.S. Geological Survey, General Interest Publications of the U.S. Geological Survey, $28 \mathrm{p}$.

[22] Lavrushin, V.Y. (2012) Subsurface Fluids of the Greater Caucasus and Its Surrounding (Vol. 599). Publ. of the USSR Acad. of Sci., Moscow.

[23] Surinder, S., Arvind, K., Bikramjit, S., Sandeep, M., Vinod K. and Sunil, D. (2010) Terrestrial, Atmospheric and Oceanic Sciences, 21, 685-695.

[24] Scholz, C.H., Sykes, L.R. and Aggarwal, Y.P. (1973) Earthquake Prediction: A Physical Basis. Science, 181, 803-810. http://dx.doi.org/10.1126/science.181.4102.803 